\title{
Funding evaluation model for the implementation of wastewater treatment projects through public private partnerships
}

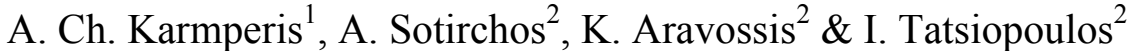 \\ ${ }^{I}$ Directorate of European and Developmental Projects Management, \\ Ministry of Defence, Greece \\ ${ }^{2}$ National Technical University of Athens, Greece
}

\begin{abstract}
This paper examines the assessment and funding rate estimation process for the implementation of wastewater treatment (WT) projects through Public Private Partnerships (PPPs). The study, having as strong theoretical foundation the Cost Benefit Analysis (CBA) methodology and the quantitative Value for Money (VfM) assessment process, develops a new algorithmic type model, in order to present a process for the funding evaluation of PPP type WT project's initial investment. The model applies in those projects that are considered to be financed by both public and private sectors and further could be potentially co-financed by the European community. The model is tested in a WT project case study and calculates the upper and lower limits of the public and private sectors' funding rates in the initial investment. Due to the fact that a PPP is not a solution option but may be the procurement choice for a preferred solution option, the new model can be a useful tool to project examiners during the feasibility stage of WT projects, in order to evaluate alternative funding scenarios and propose the most suitable in each case option to decision-makers.
\end{abstract}

Keywords: wastewater treatment projects, public private partnerships, model, evaluation, cost benefit analysis, value for money, funding scenarios.

\section{Introduction}

Public Private Partnerships (PPPs) are contract types that have been used worldwide by the majority of countries over recent decades [1,2]. Reeves [3], 
underlines that there is no common definition of PPPs, so definitions given by many authors show little differences $[4,5]$. However, a common point between different approaches is that PPP contracts are long-term agreements for cooperation between the public and private sector to provide high quality infrastructure, products or services, delivered via a process of applied risk-sharing, resources and profits, while the duration of a PPP project's operational phase is 10 to 30 years [6]. However, an undeniable fact is that PPP projects have been rapidly increased over the last decades. For the period 1990 to 2007, the World Bank Group's database [7] shows that the peak of investment projects in the water and sewerage sector was in 1997. Additionally, in 2007, investments in the specific sector amounted to US\$ 3 billion, within the US\$ 2 3 billion range of the three previous years. For the period 1985 to 2004, water and sewerage sector projects through PPPs in the United States were $41 \%$ out of 364 in total and cost US\$ 82 billion [8]. In Central-East Asia, large water projects were implemented through PPPs [9]. Specifically, WT projects have been executed in Shanghai and Chengdu, China, in Ahmedabad and Chennai, India, in Surabaya, Indonesia, in Bangkok, Thailand and in Ho Chi Minh, Vietnam, [10, 11], mainly following the Build Operate Transfer (BOT), which is the most used type in PPPs [12]. Moreover, for WT projects implementation, BOT contracts have been also used in Izmit, Turkey, in Chihuahua, Mexico, in Johor, Malaysia, a Build Own Operate contract in Sydney, Australia, full privatization contracts in England and Wales [13]. In the European Union (EU) also, PPP markets are continuously growing according to each country's model. This fact led the Commission to publish the guidelines for PPPs [14], as well as the green book on PPPs [15], which is a book of 22 questions, in order to collect data from member states and establish a common legislative framework. Conclusively, due to fiscal limitations that the global economic crisis induces, it is expected that PPP contracts will continue to play an important role in future public procurements.

\section{Evaluation of PPP projects}

In the literature, several methods for the financial evaluation of PPP projects are suggested, including the Cost Benefit Analysis (CBA) [16] and the Public Sector Comparator (PSC) [17]. Generally, it is recommended that all public procurements of goods and services should be based on the best Value for Money (VfM), which is defined as the optimum combination of whole life cost and quality, in order to meet the requirement [18]. According to Grimsey and Lewis [19], main alternative approaches that can be distinguished, are the full CBA of the public and private options, the PSC before bids invited and the United Kingdom (UK) style of VfM assessment. Particularly, in the UK as well as in Australia, the qualitative and quantitative processes that are used to determine the VfM, take into consideration all the costs and benefits included in a project's lifecycle [20]. Moreover, in the UK Private Finance Initiative (PFI) projects, incorporated in PPP programmes, were also developed. These kinds of projects, which started in 1992, had doubled by 1994, reached almost 500 in 
2002 [21] and there were approximately 668 by the end of 2009 [22]. PFI are based in public services provision, operated and also financed by the private sector [23, 24]. Currently, the existing UK guide for the VfM assessment [25] describes the methodology of approaching and estimating the VfM that results by the comparison of the PFI against the conventional procurement options. Indicatively, the quantitative assessment is accomplished with a spreadsheet, by following the instructions of the corresponding guide [26], with the appropriate time risk allocation, which is a critical success factor in PPP projects [27], to those parties that are best able to manage [28]. On the other hand, the CBA methodology as it is presented in the CBA guide for investment projects, issued by the European Commission [29], has six basic steps, including the financial and economic analysis. A remarkable point is that project proposals have to include CBA for all large projects co-financed by the European Community for the 2007-2013 period, where projects considered to be large are those in which the environmental projects budget is over $€ 25$ million and over $€ 50$ million for the other categories [30]. The main purpose of the financial analysis is to use the project cash flow forecasts, in order to calculate the Financial Net Present Value (FNPV) and Financial Rate of Return (FRR). Cash flows arising in different years of the project's lifecycle are calculated by the discount rate (discount flow analysis) in order to adapt to the present value of future flows [31]. Particularly in PPPs, it is recommended that financial analysis should include calculations of the FRR (Kg) and FRR (Kp) indicators, respectively for the public and the private investor. Additionally, economic analysis evaluates the contribution of the project to the economic welfare of the country and is executed on behalf of the whole of society. The key concept is the use of accounting shadow prices, based on the social opportunity cost, instead of observed distorted prices, in order to calculate the Economic NPV (ENPV) and the Economic IRR (ERR). Economic analysis' methodology is divided into five steps: conversion of market to accounting prices, monetisation of non-market impacts, inclusion of additional indirect effects, discounting of the estimated costs and benefits and calculation of the relative indicators, ENPV, ERR and $\mathrm{B} / \mathrm{C}$ ratio.

\section{Economic analysis of wastewater treatment projects}

Initially, it has to be mentioned that the most effective way of reducing WT needs and costs, is to reduce the domestic water consumption through an effective water demand management [32]. The second step is the development of WT projects, which have to be planned according to collection and treatment characteristics [33] and the criteria for the selection of the appropriate system are based on factors such as the population density, the produced wastewater volume, the presence of shallow water wells susceptible to wastewater pollution, the soil permeability, the unit cost of wastewater collection and the socioeconomic and cultural considerations. However, due to the fact that WT projects should be examined on a case by case basis, the critical point is to distinguish the resulting benefits of the project. Specifically, in dealing with the impact of waste water, boundaries for downstream effects should be clear, either including the 
area affected immediately, or consider the impacts on irrigation, fishing and drinking water [34]. Moreover, due to the fact that typical environmental impacts are associated with the water quality as well as the soil and groundwater quality, the decrease or increase of the waters' quantity or quality produces some gains or losses in social benefits, while the economic value measurement uses actual related market prices. In the case that market prices do not exist, relevant approaches should be followed. The most common approach is the use of the contingent valuation (CV) method, which is a survey-based method frequently used for placing monetary values on goods and services not bought and sold in the marketplace, for the evaluation of a consumer's willingness to pay for different product/services attributes. Additionally, in the non-market goods appraisal, there is also the Benefit Transfer Approach specifically for environmental goods and services [35], while approaches are also suggested in valuing time, health benefits, landscape or water [36].

\section{Case study: evaluation of a wastewater treatment project}

The target of this study is to test a hypothetical WT project in both the above evaluation methods, VfM quantitative assessment and CBA, and to combine them suitably by developing a process that could be used in funding evaluation, during a project's feasibility stage. Indicatively, the case study aims to evaluate alternative funding scenarios. The market price, as well as the standard conversion factor and conversion factors that the specific case study uses, are equal to the values of the European CBA guides' relevant case study. Moreover, the initial investment cost is divided equally in the implementation phase's years, while data used have rounded prices for the sake of simplicity. The project is an investment in the field of waste water treatment, for the reuse of well purified waste water for multiple purposes after an intensive tertiary treatment process. It takes place in a member state of the EU and includes the construction of a new water purifier for a city of 200.000 residents in the initial year, while the population grows with an annual rate of $0.5 \%$. Currently, wastewater is discharged untreated into the river crossing the city and part of the water supply is obtained through wells, subjecting the groundwater to an over-abstraction. For this reason, the local aquifer has been depleted, and its hydro geological level has been considerably lowered in recent years. Public authorities decided to examine the funding alternatives of the preferred option, which is the construction of the new water purifier, in order to decide about the funding rates of each participant, i.e. public and private financing in combination with the co-financed EU's grant.

\subsection{Assumptions: general}

The specific project includes a two year implementation and the 18 year operation of the WT system phases and only financial inflows and outflows are considered. 


\subsubsection{Initial investment, expenditures and revenues}

The cost of the initial investment is estimated to be $€ 30$ million, with a $4,5 \%$ escalator rate. This is divided into $10 \%$ for the feasibility and technical studies, $5 \%$ in land expropriation, $25 \%$ in labour, $20 \%$ in materials for civil works, $10 \%$ in transports and rentals and $30 \%$ in electromechanical equipment. This cost is $10 \%$ higher under the PPP option, as more risk is transferred. The annual operational expenditures (employment) for the initial year of the operational phase are estimated to be $€ 630.000$ in Present Value (PV), which follows a 3,5\% escalator rate. On the other hand, the non employment operational expenditures are $€ 200.000 /$ year and the Life Cycle costs, i.e. the annual basis investments during the contract period to maintain the asset so that it remains fit for its intended purpose, are estimated to be $€ 450.000$ for the $1^{\text {st }}$ year, which both follow a $2,5 \%$ escalator rate. These costs are met by the private contractor as outflows, while inflows are the annual payments from the public sector. Taking into consideration that the actual daily water supply is estimated to be 190 $1 t /$ resident, which has a reduction factor of 0,8 due to water network leakages, and that the purification charge will be $€ 0,32 / \mathrm{m}^{3}$, expected revenues are: $200.000 \times 190 \times 365 \times 0,8 / 1000 \times 0,32=3.550 .720 € / 1^{\text {st }}$ year, altered by $2 \%$ annually $(1,5 \%$ the inflation and $0,5 \%)$.

\subsubsection{Discount rate}

According to the European Guide to CBA, the discount rate that is suggested for investment calculating in the Euro zone during the 2007-2013 period is 5\%. Notwithstanding the above rate may vary depending on macroeconomic conditions, or depending on the type of investment, e.g. in PPP projects. For the present project $6 \%$ will be taken as the nominal discount rate, based on the Green Book real discount rate of 3,5\% [36], and GPD deflator assumption of 2,5\%.

\subsubsection{Positive and negative externalities}

Critical factors that project examiners should take into account are the positive and negative external impacts from the WT plant operation, i.e. the costs and benefits arising to the users, relative costs and benefits for the water resource itself and for the environment in general. Due to the fact that the water supply services is a classic case of a monopoly market, the revenues collected by the owner, even if corrected by means of appropriate conversion factors, do not represent the project's social benefits. Indicatively, some recognised externalities are presented:

4.1.3.1 Negative externalities In the local area there are costs due to the noise, odours, and aesthetic and landscape impacts of the plant. However, for the sake of simplicity, the present case study assumes that the estimated hedonic price is $1.000 .000 /$ year, equal to the difference between the market value of the rent for the buildings in the area before the plant is built and the value after the plant is built.

4.1.3.2 Positive externalities The main benefit arising from the specific project's implementation is the groundwater resource saving with the protection 
of the local hydro-geological level, as well as the generation of many positive environmental effects. Taking an accounting price of $€ 0,6$ per cubic meter of treated water, the benefits are valued at $€ 6.657 .600 /$ year. Additionally, with the use of an accounting price of $€ 0,7 / \mathrm{m}^{3}$ for the environmental protection of water and land and the safeguarding of human health and the integrity of human species, environmental benefits have an estimated value of $€ 7.767 .200 /$ year.

\subsection{Quantitative VfM assessment}

In the case of the quantitative VfM assessment process, which includes the comparison of the Conventional Procurement (CP) against the PFI options, the economic impact, either positive or negative, of the indirect VfM factors should be taken into account. However, only the factors that are likely to arise differentially under one of the tested options are calculated. In the present case study, it is assumed that the PFI option has a 2 million NPV against the CP option (due to risk allocation, design quality, etc). Additionally, the lifecycle cost is taken into account for both options, which represent the cost that is invested during the lifecycle of the project, so the asset remains fit for its intended purpose. The input sheet for the specific case study is illustrated in Table 1. The result of the spreadsheet for a pre tax target Equity IRR of $18 \%$, is the "Indicative" VfM value of $22,70 \%$ in favour of the PFI Option, i.e. the PFI is expected to have better VfM than the CP option. Furthermore, the point analysis shows that the switching value of capital expenditure factor is $-30 \%$, while the relative switching value of the unitary charge is $+32 \%$. These values lie outside the default benchmark tolerances of $-5 \%$ and $3 \%$, respectively. However, this process does not take into account the revenues that arise by the charging of users, since the payments to the SPV by the state through the unitary charge are adjusted according to the pre tax equity IRR that is used each time. On the other hand, the revenues arising from the investment process, as well as the cofinancing rate by other organizations, are considered during the CBA. The process flowchart for funding evaluation with the combination of the above methodologies is illustrated in figure 1.

\subsection{Cost benefit analysis}

Taking into consideration the revenues that the owner will have by the users' charging, it is proposed that project examiners should evaluate alternative funding rates of the initial investment scenarios in the decision making process. Due to the fact that the project will take place in a EU member state, it is crucial that the initial estimation of the maximum amount to which the co-financing rate of the priority axis applies, with the use of funding gap rate, follows the funding gap method. In the present case, the funding gap rate is calculated to be $11,22 \%$, i.e. the maximum EU contribution is $30 \times 10^{6} \times 0,1122=3,366 \times 10^{6} €$.

\subsection{Funding evaluation model}

The suggested process includes the initial calculation of the investment's indicators under a base case scenario, taking into consideration the maximum EU 
funding and further the analysis of these indicators under different funding rates in the initial investment.

\subsubsection{Base case and alternative scenarios}

The EU contributes to the initial investment funding at $11,22 \%$ and the remaining $88,78 \%$ is covered equally: $44,39 \%$ for each of the public sector and the SPV. Indicatively, public funding includes an amount of $€ 6.658 .500$ $(22,195 \%$ of investment costs) by equity, while the remaining $22,195 \%$ is provided by a national or regional fund. Additionally, the private financing (€ $13.317 .000)$ is given by equity for $10 \%$ of the amount $(€ 1.331 .700)$ and by loan for the other $90 \%(€ 11.985 .300)$, where the loan has a $6 \%$ interest rate with an amortization period of 10 years. The service fee paid to SPV is set at $€ 0.256$ per cubic metre of treated water. Calculations of the returns on Local Public capital and Private Equity and the economic analysis of the base case scenario are illustrated in Table 2. For these calculations, it has been taken for granted that the rest of the initial investment, which is not covered by EU funding, is divided equally $(44,39-44,39 \%)$ between public and private participants. The next step is to analyze various levels of public and private participation, while maintaining full use of the EU funding.

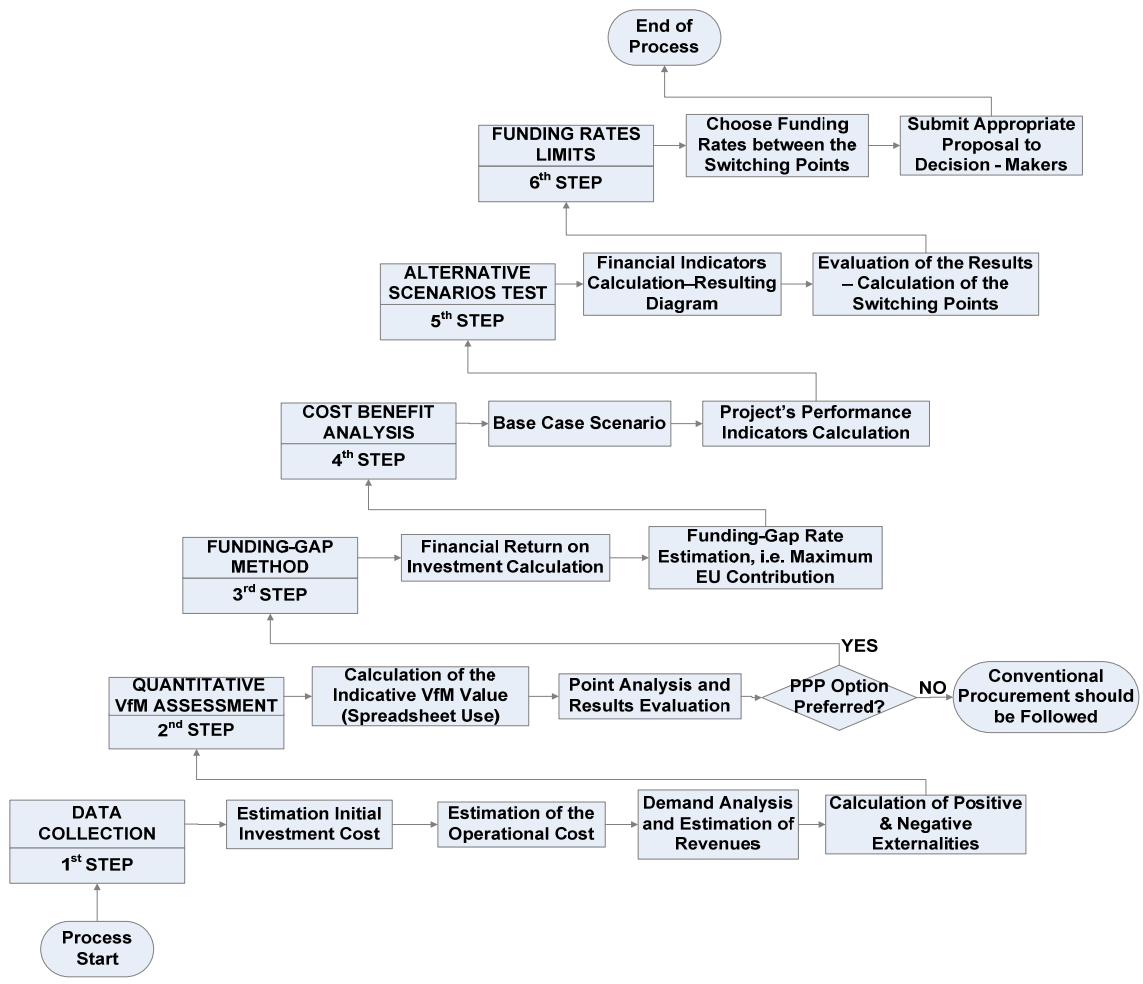

Figure 1: Funding evaluation process flowchart for the implementation of wastewater treatment projects through public private partnership. 


\subsubsection{Calculations}

Calculations of the project's performance indicators under the alternative funding scenarios are also illustrated in Table 2. Furthermore, the resulting diagram, which is presented in Figure 2, demonstrates that the four alternative scenarios result in negative financial indicators either for the public or the private participant. Taking into consideration that the financial indicators of both participants should have positive values, the switching points' calculations are critical, as they reflect the upper and lower limits of the public and private organizations funding rates, as presented in Figure 3. Following the trial and error method, the evaluation process includes the calculation of the switching point's value. For the present case study, as shown in Figure 3, the first switching point value is $31,38 \%$ for the SPV and $57,4 \%$ for the public sector (27,8\% by national or regional fund and $28,7 \%$ by local public capital) and the second switching point value is $63,18 \%$ for the SPV and $25,6 \%$ for the public sector $(12,8 \%$ by national or regional fund and $12,8 \%$ by local public capital). These values present the upper and lower limits of the funding rates that the public and private participants should contribute in the initial investment, so project examiners have to go further in the risk assessment of the CBA, by choosing funding rates between these limits.

\subsubsection{Process flowchart}

The total process flowchart is illustrated in Figure 1 and presents a new algorithmic type model, which could be used in the funding evaluation process of WT projects implementation through PPPs.

\section{Conclusions}

The current study examines the initial funding estimation process executed by project examiners during the feasibility stage of WT projects and develops a new algorithmic type model, which follows the option analysis. The new model presents the project examination process in the procurement option under PPPs and specifically the implementation of BOT contracts, where both public and private sectors participate in the initial investment funding. The model is divided into six steps. Initially, it includes the collection of the appropriate data and further the quantitative VfM assessment process in order to demonstrate that the PPP procurement option includes enough VfM. Additionally, the new model takes into consideration that the project will be implemented in a EU member state, so the CBA methodology is used, which includes the funding-gap rate estimation. Later, the financial as well as the economic analysis of a base case scenario are examined, where the rest of the initial investment is covered equally by the public and the private sector. Moreover, the algorithm includes the calculation of various levels of funding rates for both participants and indicatively the switching points, where the FNPV indicators of public and private sectors are positive, i.e. both FRRs are equal to or greater than the discount rate. Switching points resulting from process present the upper and 


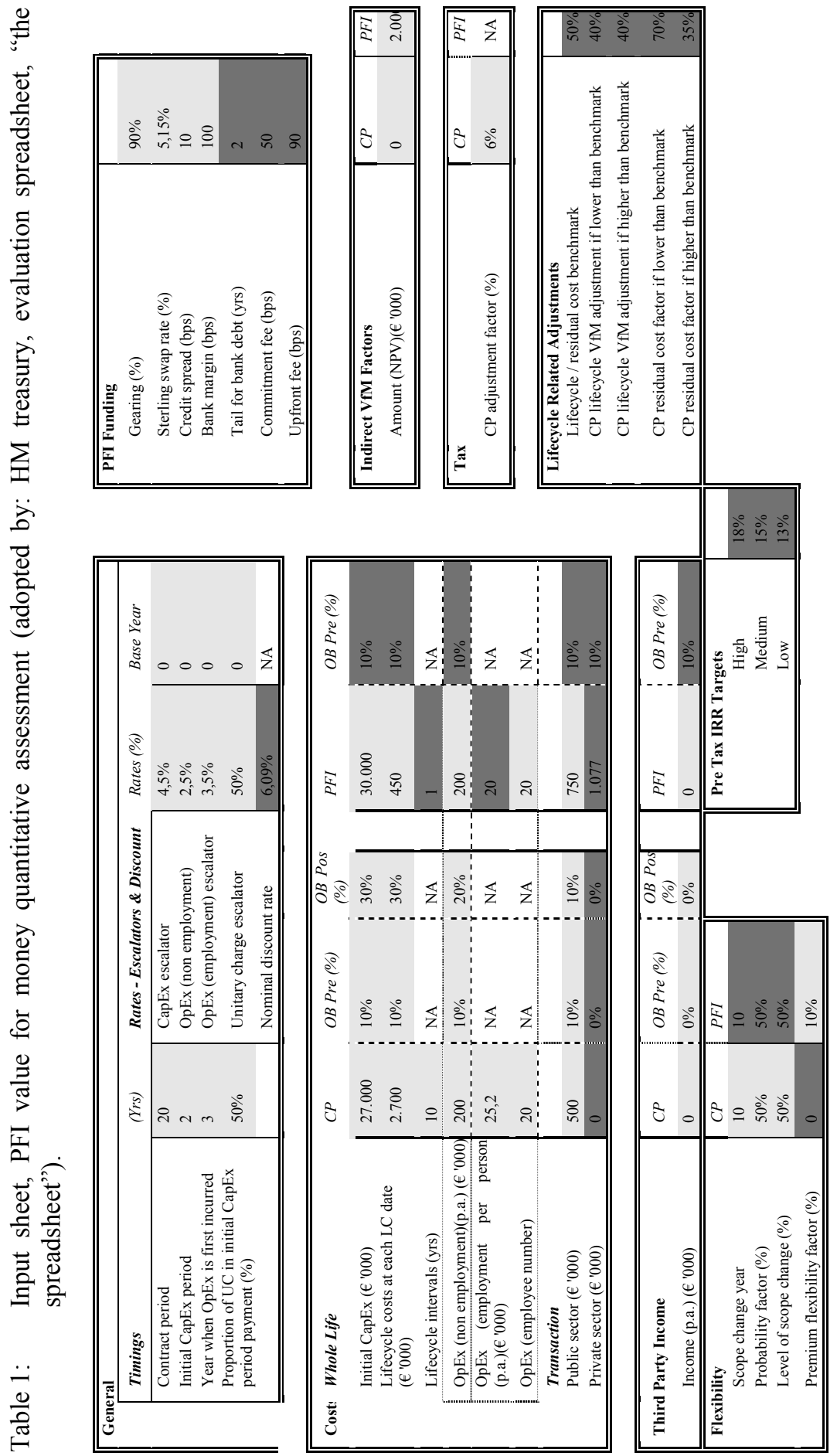

WIT Transactions on Ecology and the Environment, Vol 131, (C) 2010 WIT Press www.witpress.com, ISSN 1743-3541 (on-line) 
Table 2: $\quad$ Calculations - funding scenarios.

\begin{tabular}{|c|c|c|c|c|c|}
\hline Scenarios & $1^{\mathrm{st}}$ & $2^{\text {nd }}$ & Base Case & $3^{\text {rd }}$ & $4^{\text {th }}$ \\
\hline $\begin{array}{c}\text { EU } \\
\text { Contribution }\end{array}$ & $11,22 \%$ & $11,22 \%$ & $11,22 \%$ & $11,22 \%$ & $11,22 \%$ \\
\hline \multicolumn{6}{|c|}{ Public Contribution } \\
\hline $\begin{array}{c}\text { Local Public } \\
\text { Capital }\end{array}$ & $\begin{array}{r}12.750 .000 € \\
(42,5 \%)\end{array}$ & $\begin{array}{r}9.750 .000 € \\
(32,5 \%)\end{array}$ & $\begin{array}{r}6.658 .500 € \\
(22,195 \%\end{array}$ & $\begin{array}{r}3.567 .000 € \\
(11,89 \%)\end{array}$ & $\begin{array}{r}567.000 € \\
(1,89 \%)\end{array}$ \\
\hline $\begin{array}{c}\text { National/ } \\
\text { Regional Fund }\end{array}$ & $\begin{array}{r}12.750 .000 € \\
(42,5 \%)\end{array}$ & $\begin{array}{r}9.750 .000 € \\
(32,5 \%)\end{array}$ & $\begin{array}{r}6.658 .500 € \\
(22,195 \%\end{array}$ & $\begin{array}{r}3.567 .000 € \\
(11,89 \%)\end{array}$ & $\begin{array}{r}567.000 € \\
(1,89 \%)\end{array}$ \\
\hline Total & $\begin{array}{r}25.500 .000 € \\
(85,0 \%) \\
\end{array}$ & $\begin{array}{r}19.500 .000 € \\
(65,0 \%) \\
\end{array}$ & $\begin{array}{r}13.317 .000 € \\
(44,39 \%) \\
\end{array}$ & $\begin{array}{r}7.134 .000 € \\
(23,78 \%) \\
\end{array}$ & $\begin{array}{r}1.134 .000 € \\
(3,78 \%) \\
\end{array}$ \\
\hline \multicolumn{6}{|c|}{ Private Contribution } \\
\hline Equity & $\begin{array}{r}113.400 € \\
(0,378 \%)\end{array}$ & $\begin{array}{r}713.400 € \\
(2,378 \%) \\
\end{array}$ & $\begin{array}{r}1.331 .700 € \\
(4,43 \%)\end{array}$ & $\begin{array}{r}1.950 .000 € \\
(6,50 \%)\end{array}$ & $\begin{array}{r}2.550 .000 € \\
(8,5 \%)\end{array}$ \\
\hline Loan & $\begin{array}{r}1.020 .600 € \\
(3,402 \%) \\
\end{array}$ & $\begin{array}{r}6.420 .600 € \\
(21,402 \%)\end{array}$ & $\begin{array}{r}11.985 .300 € \\
(39,96 \%)\end{array}$ & $\begin{array}{r}17.550 .000 \\
€(21,402 \%)\end{array}$ & $\begin{array}{r}22.950 .000 \\
€(76,5 \%)\end{array}$ \\
\hline Total & $\begin{array}{r}1.134 .000 € \\
(3,78 \%)\end{array}$ & $\begin{array}{r}7.134 .000 € \\
(23,78 \%)\end{array}$ & $\begin{array}{r}13.317 .000 € \\
(44,39 \%)\end{array}$ & $\begin{array}{r}19.500 .000 \\
€(65,0 \%)\end{array}$ & $\begin{array}{r}25.500 .000 \\
€(85,0 \%)\end{array}$ \\
\hline FNPV(Kg) & -3.795 .000 & -1.045 .000 & +1.789 .000 & +4.623 .000 & +7.373 .000 \\
\hline FRR(Kg) & $+1,722 \%$ & $+4,571 \%$ & $+9,214 \%$ & $+19,050 \%$ & $+88,600 \%$ \\
\hline FNPV(Kp) & +15.269 .000 & +10.124 .000 & +4.823 .000 & -470.000 & -7.793 .000 \\
\hline FRR(Kp) & $+390,00 \%$ & $+69,80 \%$ & $+17,97 \%$ & $+5,258 \%$ & $-2,437 \%$ \\
\hline ENPV & +124.988 & +124.988 & +124.988 & +124.988 & +124.988 \\
\hline ERR & $+46,138 \%$ & $+46,138 \%$ & $+46,138 \%$ & $\begin{array}{r}+ \\
46,138 \% \\
\end{array}$ & $+46,138 \%$ \\
\hline
\end{tabular}

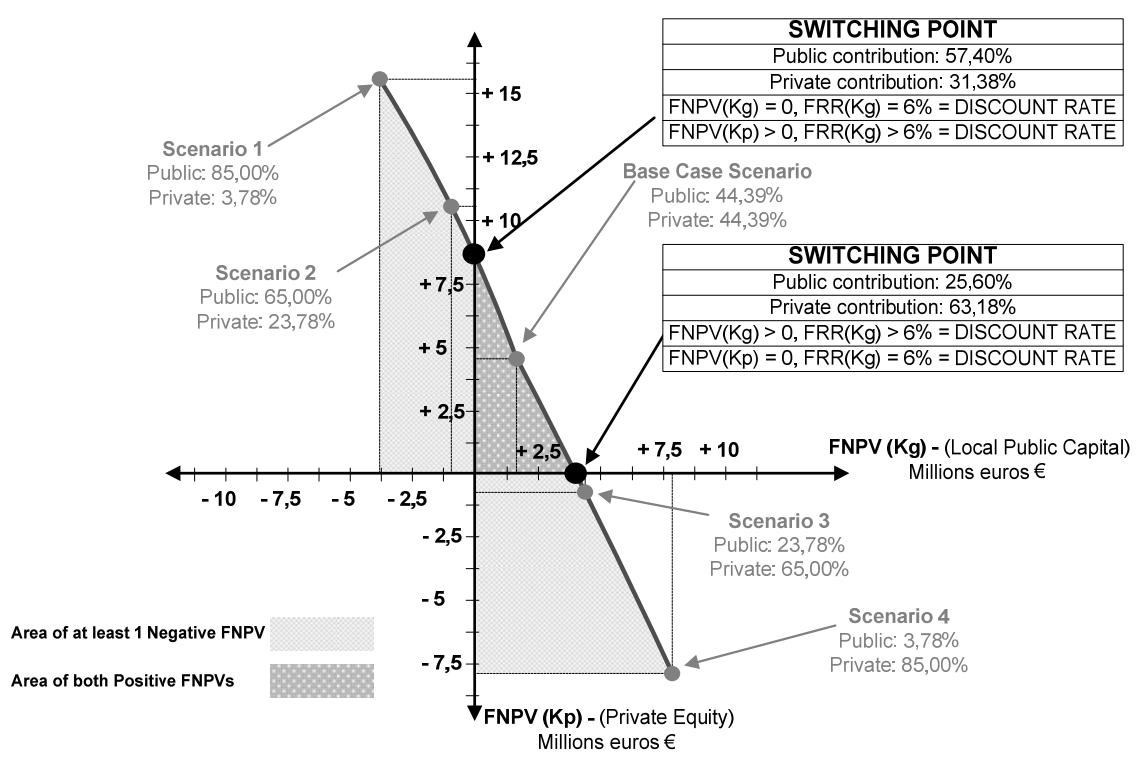

Figure 2: Evaluation of the alternative funding scenarios (switching points) for public and private funding in the initial investment scenarios. 


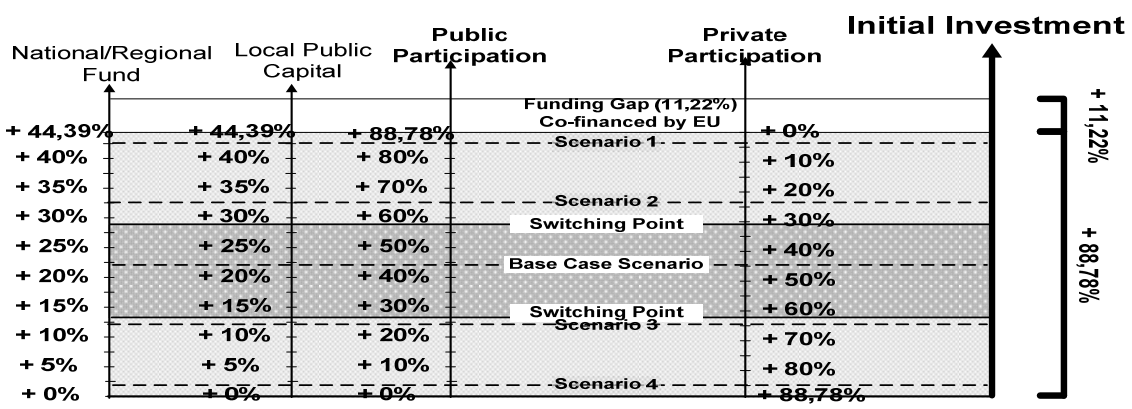

Figure 3: Results of the evaluation process.

lower limits, which include the possible values of the funding rates that the public and the private sectors should contribute in the initial investment. The new model is tested in a hypothetical case study, where the implementation through PPP of a WT project is examined. The model can be used by the project examiners during the feasibility stage of a project, in order to submit the appropriate proposals to decision makers about the funding rates that the participants should contribute in the project's initial investment.

\section{References}

[1] Pongsiri, N., Regulation and public private partnerships, International Journal of Public Sector Management, 15(6), pp. 487-495, 2002.

[2] Jones, R. \& Noble, G., Managing the Implementation of Public-Private Partnerships, Public Money and Management, 28(2), pp.109-114, 2008.

[3] Reeves, E., Public Private Partnerships in the Irish Roads Sector: an Economic Analysis, Research in Transportation Economics, 15(1), pp. 107-120, 2005.

[4] Grimsey, D. \& Lewis, M.K., Evaluating the risks of public private partnerships for infrastructure projects, International Journal of Project Management, 20(2), pp. 107-118, 2002.

[5] Bovaird, T., Public-private partnerships: from contested concepts to prevalent practice, International Review of Administrative Sciences, 70(2), pp. 199-215, 2004.

[6] Evans, G. \& Bowman D., The Challenge of Public Private Partnerships: Learning from International experience, Edward Elgar publ, pp.64-65, 2005.

[7] World Bank Group, PPP in Developing Countries, 2007 data results from the PPI Project Database, The World Bank Group, Public Private Infrastructure Advisory Facility, pp. 13-19, http://ppi.worldbank.org/

[8] Federal Highway Administration, Synthesis of public private partnership projects for roads, bridges and tunnels from around the world 1985-2004, U.S. Department of Transportation, Washington, D.C., pp. 9-10, 2005. 
[9] Panggabean, A.T.P., Expanding Access to Basic Services in Asia and the Pacific Region: Public-Private Partnerships for Poverty Reduction, Asian and Development Bank, ERD Working Paper, No 87, pp. 1, 7, 14, 2006.

[10] Chiu, Wai-ip, How to Launch a Successful BOT Project, Edmond University of Hong - Kong, Thesis submitted, p. 34, 1998.

[11] Asian Development Bank, Technical Assistance for Public Private Community Partnerships in Urban Services for the poor, A. 2, pp. 1-2, 2000.

[12] Zhang, X-q. \& Kumaraswamy, M. M., Hong Kong experience in managing BOT projects, Journal of Construction Engineering and Management, 127(2), pp. 154-162, 2001.

[13] Haarmayer, D. \& Mody, A., Financing Water and Sanitation Projects The Unique Risks, The World Bank Group, Finance, Private Sector and Infrastructure Network, 151, pp. 1-4, 1998.

[14] European Commission, Guidelines for Successful Public - Private Partnerships, Directorate - General Policy, p.14, 2003.

[15] European Commission, Green Book on Public Private Partnerships, Directorate - General Policy, COM 327, final, 2004.

[16] United Nations, Guidebook on Promoting Good Governance in Public Private Partnerships, Economic Commission for Europe, pp. 68-69, 2008.

[17] HM Treasury, How to appoint and work with a preferred bidder, Technical Note No. 4, Treasury Taskforce, Private Finance, HMSO, London, 1999.

[18] Office of Government Commerce, Green public private partnerships, Norwich, pp.4-5, 2002.

[19] Grimsey, D. \& Lewis M.K., Are Public Private Partnerships value for money? Evaluating alternative approaches and comparing academic and practitioner views, Accounting Forum, 29(4), 2005, pp. 345-378, 2005.

[20] HM Treasury, Value for money assessment guidance, London, 2004.

[21] Spackman, M., Public-private partnerships: lessons from the British approach, Economic Systems, 26(3), pp. 283-301, 2002.

[22] HM Treasury, http://www.hm-treasury.gov.uk/d/pfi_signed_projects list.xls

[23] HM Treasury, PPP's, the Government's Approach, p.10, London, 2000.

[24] Department for Transport, Green Public Private Partnership, UK, p.4, 2002.

[25] HM Treasury, Value for Money Assessment Guidance, London, 2006.

[26] HM Treasury, PFI Value for Money Quantitative Assessment, Evaluation Spreadsheet, $\quad$ http://www.hm-treasury.gov.uk/d/vfm_qe_spreadsheet 0307.xls

[27] Zhang, X., Critical Success Factors for PPPs in Infrastructure Development, Journal of Construction Engineering \&Management, 131(1), pp. 3-14, 2005.

[28] Van Ham, H. \& Koppenjan, J., Building PPPs: Assessing and managing risks in port development, Public Management Review, 4(1), pp. 593-616, 2002. 
[29] European Commission, Guide to Cost-Benefit Analysis of Investment Projects, pp. 13 - 15, 2008.

[30] European Union Official Journal, Council Regulation (EC) No 1083/2006, of 11 July, 2006: Chapter II, Section 2, Article 39-40, 2006.

[31] Project Management Institute, $P M B O K, 4^{\text {th }}$ ed, p.168, 2008.

[32] United Nations, Guidelines on Municipal Wastewater Management, UN Environmental Programme, pp.48-51, 2004.

[33] Organisation for Economic Cooperation \& Development, Handbook for Appraisal of Environmental Projects Financed from Public Funds, Environmental Finance, pp. 64 - 66, 2007.

[34] Asian Development Bank, Guidelines for the Economic Analysis of a Project, Economics and Development Resource Centre, p. 167, 1997.

[35] Pearce, D., Atkinson, G. \& Mourato, S., Cost-Benefit Analysis and the Environment: Recent Developments, OECD publishing, pp. 253-267, 2006.

[36] HM Treasury, The Green Book: Appraisal and Evaluation in Central Government, London, Annex 2: Valuing non market impact, pp. 57-67, 2004. 